\title{
Interpretasi Konstitusi dalam Pengujian Konstitusionalitas untuk Mewujudkan The Living Constitution
}

\author{
"Interpretation of the Constitution for \\ Constitutionality Testing to Create the Living \\ Constitution"
}

\author{
Fakhris Lutfianto Hapsoro ${ }^{1}$ \\ Ismail $^{2}$
}

1Fakultas Hukum Universitas Padjajaran Bandung, Jawa Barat, Indonesia. E-mail: fakhris18001@mail.unpad.ac.id

2Fakultas Hukum Universitas Bung Karno, Jakarta, Indonesia. E-mail: ubkismail@gmail.com

\section{Info Artikel}

\section{Kata Kunci:}

Interpretasi Konstitusi; Pengujian

Konstitutionalitas; The Living Constitution.

\section{Cara Mengutip (APA}

Citation Style):

Hapsoro, F.L, dan Ismail. (2020). " Interpretasi Konstitusi Dalam Pengujian

Konstitutionalitas Untuk Mewujudkan The Living Constitution, JALREV 2 (2): $139-160$

\begin{abstract}
Abstrak
Tujuan dari tulisan ini yaitu untuk menjelaskan kewenangan Mahkamah Konstitusi menguji konstitusionalitas undang-undang terhadap undangundang dasar dalam hal ini kewenangan memberikan interpretasi terhadap UUD NRI 1945. Terkait dengan interpretasi konstitusi, maka suatu undang-undang dasar tidak hanya dianggap sebagai suatu documented constitution melainkan dapat bertransformasi menjadi the living constitution. Dalam praktik di Indonesia, dapat dijumpai putusanputusan Mahkamah Konstitusi yang menggunakan interpretasi konstitusi untuk menilai konstitusionalitas suatu norma. Metode yang digunakan dalam penelitian ini adalah pendekatan yuridis normatif. Hasil penelitian ini menguraikan sejauh mana upaya hakim dalam mewujudkan the living constitution melalui interpretasi hakim dalam pengujian konstitusionalitas. Dalam menafsirkan konstitusi, hakim bebas menggunakan metode interpretasi apapun. Namun kebebasan memilih dan menggunakan metode interpretasi tersebut harus tetap berada dalam koridor Pancasila dan UUD 1945. Hakim harus cermat, mampu memperhatikan, menggali hakekat atau merefleksikan suatu ketentuan pasal di dalam UUD sesuai dengan nilai-nilai Pancasila dan UUD 1945.
\end{abstract}




\section{Article Info}

\section{Keywords:}

Interpretation of the

Constitution;

Constitutional Review;

The Living Constitution.

\section{How to cite (APA}

Citation Style):

Hapsoro, F.L, dan Ismail. (2020). "Interpretation of the Constitution for Constitutionality Testing to Create the Living Constitution". Jambura Law Review, JALREV 2 (2): $139-160$

\begin{abstract}
The purpose of this paper is to explain the authority of the Constitutional Court to examine the Constitution of the legislation against the basic legislation in this case the authority to give an interpretation of the Constitution of 1945. In relation to the interpretation of the Constitution, basic law is not only regarded as a documented constitution but can transform into a living constitution. In Indonesia's practice, the Constitutional Court's decision can be found which uses the interpretation of the Constitution to assess the constitutionality of a norm. The method used in this study is a normative juridical approach. The results of this study describe the extent to which the judge's efforts in realizing the living Constitution through the interpretation of judges in the examination of the constituency. In interpreting the Constitution, judges are free to use any method of interpretation. But the freedom to choose and use the method of interpretation must remain in the corridor Pancasila and the Constitution of 1945. The judge must be careful, able to observe, dig, or reflect a provision of the article in the constitution in accordance with the values of Pancasila and the Constitution 1945.
\end{abstract}

(C) 2020-Hapsoro, Fakhris Lutfianto Under the license CC BY-SA 4.0

\section{Pendahuluan}

Salah satu hasil Perubahan UUD 1945 adalah terkait dengan kekuasaan kehakiman, antara lain adanya lembaga yudisial baru yaitu Mahkamah Konstitusi. Hal tersebut menimbulkan suatu kebutuhan baru untuk memberikan landasan terhadap praktik ketatanegaraan di Indonesia. Kebutuhan tersebut berasal dari kewenangan Mahkamah Konstitusi untuk menguji undang-undang terhadap undang-undang dasar, sebagaimana telah disebutkan pada Pasal 24C ayat (1) Perubahan Ketiga UUD 1945 yaitu "Mahkamah Konstitusi berwenang mengadili pada tingkat pertama dan terakhir yang putusannya bersifat final untuk menguji undang-undang terhadap undangundang dasar, memutus sengketa kewenangan lembaga negara yang kewenangannya diberikan oleh undang-undang dasar, memutus pembubaran partai politik dan memutus perselisihan tentang hasil pemilihan umum".

Dengan kewenangan yang diberikan oleh Konstitusi kepada Mahkamah Konstitusi sebagai salah satu pelaku kekuasaan kehakiman yang berfungsi mengawal konstitusi (the guardian of the constitution) dan karena fungsinya tersebut Mahkamah Konstitusi merupakan penafsir tertinggi Undang-Undang Dasar (the ultimate interpreter of the 
constitution). ${ }^{1}$ Untuk dapat menyatakan bahwa undang-undang bertentangan dengan undang-undang dasar, diperlukan sebuah penalaran hukum yang dapat menyimpulkan bahwa ketentuan yang terdapat dalam undang-undang dasar telah dilanggar oleh sebuah undang-undang, meskipun telah mengalami perubahan yang diwujudkan dengan adanya penambahan pasal-pasal dalam undang-undang dasar, namun sebagai sebuah konstitusi yang harus digunakan oleh Mahkamah Konstitusi sebagai dasar untuk penguji undang-undang, substansi yang terdapat dalam undangundang dasar masih perlu ditafsirkan oleh Mahkamah Konstitusi.

Secara historis, penafsiran konstitusional diawali dengan adanya putusan Chief Justice Marshall terhadap putusan atas Kasus Madison vs Marbury, ${ }^{2}$ yang kemudian berkembang dalam praktik ketatanegaraan di berbagai negara, termasuk Indonesia. Melalui Perubahan Ketiga UUD 1945, dibentuklah lembaga Mahkamah Konstitusi (MK) yang kewenangannya telah diuraikan di atas. Namun, dengan adanya kehadiran lembaga MK tersebut, muncul berbagai polemik karena dengan kewenangannya, MK seringkali menghasilkan putusan yang menyebabkan adanya perubahan makna dalam teks undang-undang dasar. Hal ini menunjukkan bahwa adanya interpretasi konstitusi melalui sebuah proses peradilan (judicial interpretation), yang dimaknai sebagai sebuah teori atau metode cara berpikir yang menjelaskan bagaimana peradilan harusnya memberikan tafsir hukum terhadap sebuah undang-undang terutama undang-undang dasar.

Terkait dengan interpretasi konstitusi, K.C. Wheare berpendapat bahwa Konstitusi itu bermakna ganda atau tidak begitu jelas (vague), maka perlu ditafsirkan sesuai kebutuhan dan keinginan bangsa pada saat itu. Begitu juga Chief Justice Hughes, yang menyatakan bahwa "the constitution is what the judge say it is!",3 sehingga suatu undang-undang dasar tidak hanya dianggap sebagai suatu documented constitution melainkan dapat bertransformasi menjadi the living constitution.

\footnotetext{
1 Putusan Mahkamah Konstitusi No. 49/PUU-IX/2011, Hal. 74.

2 Feri Amsari. (2011). "Perubahan UUD 1945: Perubahan Konstitusi Negara Kesatuan Republik Indonesia Melalui Keputusan Mahkamah Konstitusi”. Jakarta: RajaGrafindo Persada. Hal. 5.

${ }^{3}$ Joachim Sanden. (2003). "Methods of Interpreting the Constitution; Estonia's Way in an Increasingly Integrated Europe". Juridica International 8: 130.
} 
Berbicara the living constitution, perkataan Hakim Stone pada tahun 1941, bahwa 'dalam masyarakat yang semakin kompleks, Kongres jelas tidak bisa menjalankan fungsinya jika ia harus menemukan semua fakta tambahan untuk menarik kesimpulan dasar yang mendukung kebijakan legislatif yang ditetapkan'. Begitu juga, dengan perkataan Sri Soemantri, 'apakah generasi sekarang dapat mengikat generasi yang akan datang? ${ }^{4}$

Kebutuhan menghidupkan konstitusi, antara lain, berkaitan dengan keinginan agar konstitusi bertahan lama dan mampu menyesuaikan dengan perkembangan. Dalam praktik, terdapat beberapa cara mengaktualisasikan konstitusi, misalnya melalui perubahan resmi, interpretasi hakim atau kebiasaan ketatanegaraan.

Dalam praktik di Indonesia, dapat dijumpai putusan-putusan Mahkamah Konstitusi yang menggunakan interpretasi konstitusi untuk menilai konstitusionalitas suatu norma seperti pada interpretasi terhadap konsep penyelenggaraan pemilu serentak, interpretasi terhadap hak menguasai atas negara, dan interpretasi terrhadap konsep otonomi daerah. Tulisan ini merupakan perkembangan dari hasil penelitian Muchamad Ali Safaat, Aan Eko Widiarti dan Fajar Laksono Suroso terkait dengan pola penafsiran konstitusi dalam putusan Mahakamah Konstitusi, dimana metode penafsiran yang digunakan pada umumnya adalah penafsiran oroginalis, dalam kategori ini yang paling banyak digunakan adalah penafsiran struktural atau fungsional dan beberapa menggunakan penafsiran historis (original intent), dan hanya ada beberapa putusan MK yang menggunakan penafsiran non originalist dengan pendekatan doktrinal atau pendekatan etik. Sementara terkait dengan bidang hukum ditemukan putusan yang menggunakan penafsiran berbeda-beda walaupun bidang hukum yang sama. ${ }^{5}$

Mencermati adanya pola yang berbeda tentang temuan pada penafsiran MK, maka dari itu, penting sekali membahas secara rinci terkait fakta-fakta kewenangan Mahkamah Konstitusi menguji konstitusionalitas undang-undang terhadap undang-undang dasar dalam kewenangan memberikan interpretasi yang ideal terhadap konstitusi agar suatu

\footnotetext{
4 Susi Dwi Harijanti. (2018). dalam Perkuliahan "Hukum Konstitusi”. Bandung: Magister Ilmu Hukum Unpad.

${ }^{5}$ Safaat, Muchamad Ali, dkk. (2017). "Pola Penafsiran Konstitui dalam Putusan Mahkamah Konstitusi Periode 2003-2008 dan 2009-2013”. Jurnal Konstitusi, 14 (2): 260
} 
undang-undang dasar tidak hanya dianggap sebagai suatu documented constitution melainkan dapat bertransformasi menjadi the living constitution.

\section{Rumusan Masalah}

Berdasarkan uraian di atas, maka dalam tulisan ini akan dibatasi dengan pertanyaan bagaimana interpretasi hakim dalam pengujian konstitusionalitas putusan-putusan Mahkamah Konstitusi untuk mewujudkan the living constitution?

\section{Metode Penulisan}

Metode yang digunakan dalam penelitian ini berupa metode yuridis normatif yaitu dengan bahan pustaka atau yang disebut data sekunder yang mencakup bahan hukum primer, bahan hukum sekunder, dan bahan hukum tersier. Dalam penenlitian ini menggunakan Pendekatan Perundang-Undangan (Statue Approach), dan pendekatan kasus (case Approach). Dalam menganalisis data, menggunakan analisis data secara kualitatif, yang selanjutnya menguraikan data secara bermutu dalam kalimat yang teratur, runtun, logis, tidak tumpang tindih, dan efektif sehingga memudahkan interpretasi data dan pemahaman hasil analisis.

\section{Interpretasi Konstitusi untuk Mewujudkan The Living Constitution}

\subsection{Konstitusi dalam Kehidupan Negara}

Konstitusi diberi makna serta pengertian yang berbeda-beda, tergantung dari cara pandang masing-masing orang. Selain itu, konstitusi dapat dipandang dari berbagai aspek seperti, hukum, politik, dan lain-lain. Cheryl Saunders mengatakan ' $a$ constitution is more than a social contract...it is rather an expression of the general will of a nation. It is a reflection of its history, fears, concerns, aspiration and indeed, the soul of the nation'. ${ }^{6}$ Pendapat hampir serupa juga disampaikan oleh guru besar Cornell University, Muna Nduldo yang menyatakan bahwa, Konstitusi sebuah negara haruslah merupakan catatan kehidupan sebuah bangsa sekaligus mimpi yang belum terselesaikan. Konstitusi itu haruslah menjadi otobiografi nasional yang mencerminkan kemajemukan masyarakatnya, harus menuliskan visi seluruh

\footnotetext{
6 Bagir Manan, dan Susi Dwi Harijanti. (2015). “Memahami Konstitusi: Makna dan Aktualisasi”. Jakarta: RajaGrafindo. Hal. 208.
} 
masyarakat dan dapat meyakinkan bahwa dalam konstitusi itu semua mimpi dan tujuan seluruh masyarakat dapat tercapai. ${ }^{7}$

Artinya sebuah konstitusi tidak hanya menjadi catatan di atas kertas sebagai simbol bahwa suatu negara telah berdiri dengan kokohnya, namun konstitusi selalu diupayakan untuk terus dilaksanakan dan dijaga oleh seluruh elemen negara, baik pemerintahan dan rakyat untuk tetap hidup dan mengatur hal-hal fundamental dalam menjamin bahwa apa yang bisa dan tidak bisa dilakukan saat proses bernegara.

Indonesia sebagai salah satu negara yang mengedepankan konstitusi disetiap aspek kehidupan berbangsa dan bernegara. Untuk itu dalam menjaga nafas konstitusi kita (UUD NRI 1945), maka dibentuklah lembaga Mahkamah Konstitusi sebagai penjaga, pengawal dan penafsir konstitusi agar dapat menjamin kehidupan negara berjalan dengan semestinya berdasarkan UUD NRI 1945.

\subsection{Perubahan Konstitusi Melalui Judicial Interpretation}

Bagi George Jellinek, perubahan konstitusi pada dasarnya dibagi menjadi dua, pertama, melalui prosedur formal (verfassungsanderung) dan kedua, melalui cara-cara informal (verfassungswandlung). ${ }^{8}$ Perubahan formal adalah perubahan yang mekanismenya telah diatur di dalam konstitusi suatu negara sedangkan perubahan di luar ketentuan konstitusi disebut sebagai perubahan informal atau melalui kondisi yang disebut oleh Djokosoetono sebagai perubahan yang terjadi secara onbewust (lambat-laun). ${ }^{9}$ Verfassungsanderung dimaknai oleh Soehardjo Sastrosoehardjo, sebagai bentuk perubahan yang sesungguhnya, dimana terjadi perubahan terhadap pokok-pokok pikiran, asas-asas, bentuk negara, sistem pemerintahan dan lainnya, sedangkan verfassungswandlung menurut Soehardjo adalah perubahan makna ataupun penafsiran ketentuan dalam konstitusi yang tidak menyimpang dari ketentuan pokok serta asas-asas yang termaktub di dalamnya. ${ }^{10}$

\footnotetext{
7 Ibid. Hal. ix.

${ }^{8}$ Djokosoetono. (2006). Kuliah "Hukum Tata Negara". Jakarta: In-Hill-Co. Hal. 131.

${ }^{9}$ Ibid.

10 Soehardjo dalam Saldi Isra dan Feri Amsari, "Perubahan Konstitusi Melalui Tafsir Mahkamah Konstitusi", Dilansir dari http://feriamsari.wordpress.com/2009/01/29/perubahan-konstitusi-melaluitafsir-mk, diakses pada 20 Juni 2019.
} 
Perubahan makna ataupun penafsiran ketentuan dalam konstitusi dapat dilakukan melalui judicial interpretation oleh badan kehakiman yang dituangkan dalam putusan pengadilan (judicial decision). Penafsiran melalui sebuah proses peradilan (judicial interpretation) dimaknai sebagai sebuah metode berpikir yang menjelaskan bagaimana peradilan memberikan tafsir hukum terhadap sebuah undang-undang dasar. ${ }^{11}$

Diperlukan banyak metode pemikiran dan alat untuk melakukan sebuah penafsiran. Metode-metode dalam menafsirkan konstitusi atau disebut juga constitutional interpretation sangatlah beragam, sehingga hakim bebas memilih metode mana yang paling cocok dengan peristiwa yang sedang ditanganinya. ${ }^{12}$ Para hakim menggunakan pandangan atau kemampuan mereka berdasarkan pemahaman mereka terhadap hukum itu sendiri. Artinya dalam melakukan interpretasi konstitusi, hakim-hakim dapat berbeda dalam memberikan interpretasi, sehingga suatu saat para hakim akan saling bertentangan dalam menafsirkan konstitusi terhadap sebuah perkara tertentu. Untuk menginterpretasi nilai yang terkandung di dalam konstitusi tertulis di suatu negara, maka dikenal beberapa metode interpretasi oleh hakim, diantaranya interpretasi gramatikal, metode ini mencoba memahami makna suatu teks atau suatu naskah aturan hukum yang mengandung kaidah-kaidah hukum dengan tolok ukur dari makna bahasa yang digunakan dalam makna teknis yuridis yang sudah dibakukan; interpretasi sitematis atau logis, metode ini membuka makna dari rumusan kaidah hukum atau istilah yang dikandung dalam tafsir sistematik yang ditentukan dengan mengacu kepada hukum sebagai sistem. Metode ini menarik makna kata-kata di dalam konteks pengaitan kalimat atau relasi antar kaidah itu sendiri; interpretasi historis, metode ini memperhitungkan kandungan konstitusi berdasarkan aspek historis; interpretasi teleologis atau sosiologis, metode ini merujuk pada penguraian formulasi kaidah hukum sesuai dengan tujuan dan jangkauan UUD. Dalam penafsiran ini memperhitungkan konteks kemasyarakatan yang ada dengan bertumpu pada makna aktual pasal tersebut; ${ }^{13}$ dan interpretasi evolutif-dinamis, metode ini

\footnotetext{
${ }^{11}$ Amsari, Feri Op.Cit. Hal. 83.

12 Marwan Mas. (2011). "Pengantar Ilmu Hukum”, Cetakan Pertama. Jakarta: Ghalia Indonesia. Hal. 141.

13 Soedikno Mertokusumo. (2014). "Penemuan Hukum”. Yogyakarta: Cahaya Atma Pustaka. Hal. 74-79.
} 
menginterpretasikan makna konstitusi atas keterkaitannya dengan sistem kemasyarakatan yang ada. ${ }^{14}$

\subsection{Konsep The Living Constitution}

Konsep the living constitution merupakan konsep penafsiran konstitusi yang berkembang di Amerika Serikat. Sebagaimana Michel Rosenfeld dan Andras Sajo menanggapi pernyataan David A. Strauss yang menyebutkan bahwa "a living constitution is one that envolves, changes over time, and adapts to new circumstances, without being formally amended". ${ }^{15}$ Menanggapi pernyataan Strauss tersebut, Michel Rosenfeld dan Andras Sajo menegaskan bahwa konsep the living constitution bukan termasuk tipologi/klasifikasi dari konstitusi, melainkan hanya sebatas cara menafsirkan konstitusi, 16

Menurut Chemerinsky, didasarkan pada realitas bahwa masyarakat modern tidak mungkin diatur oleh pandangan-pandangan spesifik individu yang hidup dua abad lalu, yaitu ketika Konstitusi Amerika Serikat diadopsi. Lebih lanjut, Chemerinsky berpendapat jika arti-arti konstitusi semata-mata hanya didasarkan pada maksud pembentuk undang-undang dasar, maka undang-undang dasar tidak akan dapat berfungsi mengatur masyarakat modern. ${ }^{17}$

Konsep the living constitution menekankan bahwa dalam menafsirkan konstitusi yang perlu diutamakan adalah perkembangan masyarakat saat ini. ${ }^{18}$ Sebagaimana yang dikemukakan oleh David A. Strauss bahwa "a living constitution is an attribute of mature society". ${ }^{19}$ Sejalan dengan pendapat Strauss, Daniel Conkle juga menyebutkan bahwa "the constitution is a living, growing document, capable of being read in a way not envisioned or intended by its framers and ratifiers at all". ${ }^{20}$ Melengkapi arti-arti the living constitution, beberapa ahli lain menyatakan bahwa 'the constitution is a living, changing document' yang harus ditafsirkan melalui elaborasi-elaborasi yang masuk akal sejalan dengan perubahan-perubahan pemahaman dan keadaan-keadaan. Bagir Manan dan

\footnotetext{
${ }^{14}$ Choirie Effendi. (2003). "Privatisasi vs Neo Sosialisme Indonesia”. Jakarta: LP3S. Hal. 84-141.

15 David A Strauss. (2010). “The Living Constitution, Oxford: Oxford University Press, 2010, Hal. 1.

16 Michel Rosenfeld, dan Andras Sajo. (2012). "Types of Constitution" dalam The Oxford Handbook of Comparative Constitutional Law, Oxford: Oxford University Press. Hal. 2.

17 Bagir Manan, dan Susi Dwi Harijanti. Op.Cit., Hal. 168.

18 Feri Amsari. Op.Cit. Hal. 88.

19 David A Strauss. Op.Cit. Hal. 117.

20 Bagir Manan, dan Susi Dwi Harijanti. Op.Cit. Hal. 169.
} 
Susi Dwi Harijanti menyimpulkan the living constitution berdasarkan pendapatpendapat yang disampaikan oleh para ahli di atas, bahwa the living constitution menunjuk pada konstitusi yang mengakomodasi perubahan-perubahan masyarakat modern melalui penafsiran yang didasarkan pada keadaan dan tuntutan yang telah berubah. $^{21}$

Paham mengenai konsep the living constitution terbagi menjadi dua kelompok, yaitu: (1) Pragmatism; dan (2) Intent. ${ }^{22}$ Kelompok pragmatis memandang bahwa penggalian terhadap masa lalu tidaklah terlalu penting, melainkan hanya catatan sejarah yang tidak memiliki korelasi yang signifikan dengan kondisi sekarang. ${ }^{23}$ Sebaliknya kalangan intent berpendapat bahwa konstitusi adalah sesuatu yang hidup dikarenakan framers of constitution membentuk konstitusi dengan maksud digunakan dalam kurun waktu yang sangat lama, sehingga konstitusi tersebut sesungguhnya fleksibel dan dan memiliki keluasan pandangan yang dapat digali pada masa kini. ${ }^{24}$ Meskipun memiliki kontras antara keduanya, Zainal Arifin Mochtar memaparkan adanya titik temu diantara kedua kelompok tersebut. Konsep the living constitution jangan dipandang sebagai paham yang anti sejarah masa lalu, konsep the living constitution dapat saja menggunakan nilai-nilai original intent dari pembentukan konstitusi selama berkesesuaian dengan kondisi masyarakat pada saat itu. ${ }^{25}$

Kemudian untuk mengetahui batasan apakah suatu putusan hasil judicial interpretation mewujudkan konsep the living constitution atau tidak, maka Feri Amsari mengungkapkan bahwa tidak terdapat kesepakatan umum mengenai metode penafsiran sehingga generasi saat ini dan yang akan datang dapat memiliki kebebasan dalam menafsirkan konstitusi sesuai dengan kondisi masyarakat pada saat itu. ${ }^{26}$ Meskipun demikian, dalam menafsirkan konstitusi guna mengaktualisasikan ketentuan-ketentuan konstitusi tidak dapat dilakukan secara bebas karena bila dilakukan sebebas-bebasnya dalam hal penggunaan nilai-nilai yang lebih diutamakan

\footnotetext{
21 Bagir Manan, dan Susi Dwi Harijanti. Ibid.

22 Feri Amsari. Op.Cit. Hal. 89.

23 Ibid.

24 Ibid.

25 Feri Amsari. Op.Cit. Hal. 90.

${ }^{26}$ Feri Amsari. Op.Cit. Hal. 92.
} 
oleh para hakim, Pengujian konstitusionalitas harus dapat ditemukan dalam konstitusi itu sendiri. ${ }^{27}$

Berdasarkan uraian konsep judicial interpretation sebelumnya, juga uraian konsep the living constitution merupakan salah satu bentuk transplantasi hukum ${ }^{28}$ yang diadopsi oleh konsep hukum di Indonesia. Keberadaan Mahkamah Konstitusi sebagai the interpreter of the constitution dilaksanakan melalui putusan-putusan dengan limitasi empat kewenangan yang diberikan oleh UUD 1945, yakni melalui perkara pengujian UU terhadap UUD, sengketa kewenangan lembaga negara yang kewenangannya diberikan oleh UUD, perkara pembubaran partai politik, dan perselisihan tentang hasil Pemilihan Umum. ${ }^{29}$

\section{Interpretasi Hakim dalam Putusan Mahkamah Konstitusi untuk Mewujudkan The Living Constitution}

Melalui kedudukan dan fungsinya, MK sebagai judicial independence dan dengan menerapkan berbagai metode rechtsvinding khususnya metode interpretasi melalui putusan-putusannya dapat mengembangkan dan menghidupkan UUD agar tetap aktual atau yang dikenal dengan sebutan 'the living constitution', 30 dalam menghadapi tantangan globalisasi hukum juga penyesuaian tradisi hukum sesuai dengan kebutuhan hukum yang dicita-citakan sebagaimana telah diamanatkan dalam Pembukaan UUD 1945 yaitu Pancasila. ${ }^{31}$

Hakim Konstitusi sejatinya harus memiliki dasar-dasar yang baik dan kuat agar dapat menjalankan konstitusi sesuai dengan koridor yang telah dituliskan dalam konstitusi suatu negara, dianataranya; memegang teguh prinsip integritas dan kepribadian yang tidak tercela, bersikap adil, bersifat negarawan, memiliki kemampuan menguasai konstitusi, dan kemampuan menguasai ketatanegaraan. ${ }^{32}$

\footnotetext{
27 Bagir Manan, dan Susi Dwi Harijanti. Op.Cit. Hal. 180.

28 Alan Watson, "Legal Transplant", Dilansir dari https://en.wikipedia.org/wiki/Legal transplant, diakses pada 20 Juni 2019.

29 Pasal 24C ayat (1) UUD 1945.

30 Bagir Manan. (2010). "Beberapa Persoalan Paradigma Setelah atau Akibat Perubahan UUD 1945". Jurnal Konstitusi. PSKN-Fakultas Hukum Universitas Padjadjaran, 2 (2): 9-10.

31 Soeprapto. (2005). "Implementasi Pancasila Dalam Kehidupan Bermasyarakat, Berbangsa dan Bernegara”. Jurnal Ketahanan Nasional, 10 (2): 19.

${ }^{32}$ Hardianto, Danang. (2014). "Hakim Konstitusi Adalah Hati dalam Tubuh Mahkamah Konstitusi". Jurnal Konstitusi, 11 (2): 317-328
} 
Seorang Hakim dalam menjalankan tugasnya memikul tanggung jawab yang besar dan ia harus menyadari tanggung jawab itu. Sebab, putusan hakim dapat membawa akibat yang sangat jauh pada kehidupan para pihak dan atau orang lain yang terkena oleh jangkauan putusan hakim tersebut, keputusan Hakim yang tidak adil dapat mengakibatkan penderitaan lahir batin yang dapat membekas sepanjang hidup para pihak. ${ }^{33}$

Untuk mengetahui implementasi hakim MK dalam menghidupkan UUD NRI 1945 maka dapat dilihat dari interpretasi yang digunakan dalam putusan-putusannya. Berikut merupakan analisis dari beberapa putusan Mahkamah Konstitusi:

\subsection{Interpretasi Mahkamah Konstitusi Terkait Hak Menguasai Negara}

Menarik dikaji terkait penafsiran MK mengenai makna hak menguasai negara sebagaimana yang dimaksud oleh Pasal 33 UUD 1945 untuk mengetahui the living constitution dari konsep hak menguasai negara tersebut. Adapun beberapa putusan yang berkaitan dengan penafsiran Pasal 33 UUD 1945 antara lain Putusan MK No. 001021-022/PUU-I/2003, Putusan MK No. 002/PUU-I/2003, Putusan MK No. 058-059060-063/PUU-II/2004, Putusan MK No. 008/PUUIII/2005, Putusan MK No. 2122/PUU-V/2007, Putusan MK No. 3/PUU-VIII/2010, dan Putusan MK No. 28/PUU$\mathrm{XI} / 2013$.

Dalam Putusan MK No. 001-021-022/PUU-I/2003, Mahkamah memberikan makna dan tafsir "dikuasai oleh negara" yang menyatakan bahwa frasa tersebut tidak dapat hanya diartikan sebatas sebagai hak untuk mengatur, karena hal dimaksud sudah dengan sendirinya melekat dalam fungsi-fungsi negara tanpa harus disebut secara khusus dalam UUD 1945. Dengan demikian frasa "dikuasai oleh negara" tidak dapat direduksi pengertiannya hanya berkaitan dengan kewenangan negara untuk mengatur perekonomian. ${ }^{34}$ Dalam hal ini Mahkamah menafsirkan secara gramatikal dengan memberikan batasan secara konstitusional terhadap hak menguasai negara dengan mengkualifikasikan kewenangan negara untuk mengadakan kebijakan (beleid) dan tindakan pengurusan (bestuursdaad), pengaturan (regelendaad), pengelolaan

\footnotetext{
33 Sakirman. (2017). “Tafsir Hukum Atas Posisi Ganda Hakim di Indonesia”. Jurnal Konstitusi, 14 (1): 194

34 Putusan Mahkamah Konstitusi No. 001-021-022/PUU-I/2003, Hal. 333
} 
(beheersdaad) dan pengawasan (toezichthoudensdaad) untuk tujuan sebesar-besarnya kemakmuran rakyat. ${ }^{35}$

Pasal 33 UUD 1945 tidaklah menolak privatisasi, sepanjang privatisasi itu tidak meniadakan penguasaan negara. Pasal 33 UUD 1945 juga tidak menolak ide kompetisi di antara para pelaku usaha, sepanjang kompetisi itu tidak meniadakan penguasaan oleh negara yang mencakup kekuasaan untuk mengatur (regelendaad), mengurus (bestuursdaad), mengelola (beheersdaad), dan mengawasi (toezichthoudensdaad) cabang-cabang produksi yang penting bagi negara dan/atau yang mengusai hajat hidup orang banyak untuk tujuan sebesar-besarnya kemakmuran rakyat. ${ }^{36}$

Pada Putusan MK No. 002/PUU-I/2003, Mahkamah menyatakan bahwa Pasal 33 UUD 1945 memiliki pengertian yang lebih tinggi atau lebih luas daripada pemilikan dalam konsepsi hukum perdata. Konsepsi penguasaan oleh negara merupakan konsepsi hukum publik yang berkaitan dengan prinsip kedaulatan rakyat yang dianut dalam UUD 1945, baik di bidang politik (demokrasi politik) maupun ekonomi (demokrasi ekonomi).

Kemudian dalam Putusan MK No. 058-059-060-063/PUU-II/2004 dan Putusan MK No. 008/PUUIII/2005, Mahkamah menegaskan bahwa pemenuhan hak asasi atas air menjadi tanggung jawab negara, artinya mewajibkan kepada negara untuk menjamin agar setiap orang dapat memenuhi kebutuhan akan air. Ketiga aspek hak asasi yang harus dijamin oleh negara, yaitu penghormatan, perlindungan dan pemenuhan, tidak hanya menyangkut kebutuhan sekarang tetapi harus juga dijamin kesinambungannya untuk masa depan karena secara langsung menyangkut eksistensi manusia. Oleh karenanya negara juga perlu terlibat secara aktif dalam perencanaan pengelolaan sumber daya air yang tujuannya untuk menjamin ketersediaan air bagi masyarakat.

Selanjutnya dalam Putusan MK No. 21-22/PUU-V/2007, Mahkamah menyatakan bahwa tujuan akhir yang hendak dicapai adalah terwujudnya perekonomian nasional yang memberikan kemakmuran yang sebesar-besarnya kepada rakyat. Mahkamah memandang perlu menegaskan bahwa adanya hak penguasaan oleh negara atas bumi, air, dan seluruh kekayaan alam yang ada di dalamnya itu menunjukkan bahwa

35 Ibid, Hal. 334.

36 Ibid, Hal. 336-337. 
konsepsi hak yang dianut oleh UUD 1945 berkenaan dengan ketiga hal dimaksud (bumi, air, dan kekayaan alam yang terkandung dalam bumi dan air itu) bukanlah konsepsi hak sebagaimana yang dikenal dalam doktrin hukum Romawi bahwa siapa yang memiliki hak atas tanah ia juga berhak atas segala yang berada di atas maupun di bawah atau di dalam tanah itu secara tak terbatas (cojus est solum est usque ad coelum et ad inferos ad infinitum). Penegasan ini penting karena salah satu isu konstitusional yang dipermasalahkan dalam permohonan a quo bersangkut-paut dengan hak penguasaan negara atas tanah. Dengan penegasan tersebut di atas, maka tiga hal menjadi jelas. Pertama, bagi negara, bahwa hak menguasai yang diberikan oleh UUD 1945 kepadanya itu bukanlah demi negara itu sendiri melainkan terikat pada tujuan pemberian hak itu yakni untuk dipergunakan bagi sebesar-besar kemakmuran rakyat; Kedua, bagi orang perorangan pemegang hak atas tanah, termasuk badan hukum, dengan penegasan tersebut berarti ada kepastian bahwa dalam hak atas tanah yang dipunyainya itu melekat pula pembatasan-pembatasan yang lahir dari adanya hak penguasaan oleh negara; Ketiga, bagi pihak-pihak lain yang bukan pemegang hak atas tanah juga diperoleh kepastian bahwa mereka tidak serta-merta dapat meminta negara untuk melakukan tindakan penguasaan atas tanah yang terhadap tanah itu sudah melekat suatu hak tertentu.

Pada Putusan MK No. 3/PUU-VIII/2010, Mahkamah menafsirkan Pasal 33 ayat (4) UUD 1945 bahwa prinsip kebersamaan harus dimaknai bahwa dalam penyelenggaraan ekonomi termasuk pengelolaan sumber daya alam bagi keuntungan ekonomi, harus melibatkan rakyat seluas-luasnya dan menguntungkan bagi kesejahteraan rakyat banyak. Pengelolaan sumber daya alam tidak boleh semata-mata memperhatikan prinsip efisiensi untuk memperoleh hasil sebanyak-banyaknya yang dapat menguntungkan kelompok kecil pemilik modal, tetapi harus dapat meningkatkan kesejahteraan rakyat secara berkeadilan. ${ }^{37}$

Selanjutnya pada Putusan MK No. 28/PUU-XI/2013, Mahkamah melakukan penafsiran dengan memberikan pemaknaan akan adanya nilai demokrasi ekonomi dalam rumusan Pasal 33 UUD 1945 dan asas kekeluargaan yang rumusannya berasal dari konsep modal sosial yang menjadi jati diri koperasi. Mahkamah menyatakan bahwa

37 Putusan No. 3/PUU-VIII/2010, Hal. 163. 
koperasi pada hakikatnya merupakan bagian dari tata susunan ekonomi Indonesia yang diamanatkan oleh Pasal 33 ayat (1) UUD 1945 yang menyatakan, "Perekonomian disusun sebagai usaha bersama berdasar atas asas kekeluargaan". ${ }^{38}$ Pasal tersebut diletakkan di dalam Bab XIV yang berjudul, "Perekonomian Nasional Dan Kesejahteraan Sosial". ${ }^{39}$ Atas dasar judul tersebut dengan mengaitkan rumusan Pasal 33 ayat (1) UUD 1945 dapat dipahami secara jelas pengertian filosofisnya. Selain itu, untuk memperoleh pengertian yang menjadi intensi dari pembentuk UUD 1945 secara lebih tepat dari pasal tersebut perlu dikutip Penjelasannya (sebelum perubahan) sebagai dokumen penting yang menyatakan, "Dalam pasal 33 tercantum dasar demokrasi ekonomi, produksi dikerjakan oleh semua, untuk semua di bawah pimpinan atau penilikan anggota-anggota masyarakat. Kemakmuran masyarakatlah yang diutamakan, bukan kemakmuran orang seorang. Sebab itu perekonomian disusun sebagai usaha bersama berdasarkan asas kekeluargaan. Bangun perusahaan yang sesuai dengan itu ialah koperasi”. Konsep modal sosial inilah yang menjadi jati diri koperasi dan sangat cocok dengan kondisi rakyat Indonesia yang telah memiliki tradisi gotong royong, yang kemudian di dalam Pasal 33 ayat (1) UUD 1945 dirumuskan sebagai usaha bersama berdasarkan asas kekeluargaan.

Pemaknaan menurut MK, adalah mencakup makna penguasaan oleh negara dalam arti luas yang berumber dan berasal dari konsepsi kedaulatan rakyat Indonesia atas segala kekayaan bumi dan air dan kekayaan alam yang terkandung di dalamnya. ${ }^{40}$

Berdasarkan uraian di atas maka dapat disimpulkan bahwa penafsiran yang dilakukan oleh MK adalah penafsiran secara teleologis dimana memberikan makna terhadap Pasal 33 UUD 1945 metode ini menginterpretasikan makna konstitusi atas keterkaitannya dengan sistem kemasyarakatan yang ada. Namun dalam menerapkan penafsiran ini, terlihat kontradiksi antara penafsiran MK dengan kehendak pembentuk UUD 1945 dalam hal ini diwakili oleh Mohammad Hatta. Hal ini terkait dengan isu pengelolaan cabang-cabang produksi dan sumber daya alam sebagaimana dimaksud dalam Pasal 33 UUD 1945. Mohammad Hatta hanya memberikan peran serta

\footnotetext{
38 Putusan No. 28/PUU-XI/2013, Hal. 237.

39 Ibid, Hal. 239.

${ }^{40}$ Winayanti, Nia Kania. (2018). "Rekonstruksi Makna Hak Menguasai Negara Berdasarkan Pasal 33 Ayat (3) UUD 1945 dalam Mewujudkan Ketahanan Ekonomi Nasional”. Jurnal Majelis, 7 (7): 93-94
} 
pengelolaan dalam cabang-cabang produksi dan sumber daya alam sebagaimana dimaksud dalam Pasal 33 UUD 1945, kepada pihak non-negara, hanya terbatas dalam kelembagaan koperasi. ${ }^{41}$ Namun di dalam pertimbangan putusan MK, terdapat penafsiran secara ekstensif dengan tidak mempersoalkan peran perorangan/swasta di dalam mengelola cabang-cabang produksi dan sumber daya alam sebagaimana dimaksud dalam Pasal 33 UUD 1945.

\subsection{Interpretasi Mahkamah Konstitusi Terkait Penyelenggaraan Pemilu Serentak}

Mahkamah Konstitusi berlandaskan pada upaya nyata untuk memberikan perlindungan terhadap hak-hak konstitusional warga negara dengan semangat penegakan konstitusi sebagai grundnorm atau highest norm, yang artinya segala peraturan perundang-undangan yang berada di bawahnya tidak boleh bertentangan atau keluar dari koridor konstitusi yang telah disepakati (UUD NRI 1945). ${ }^{42}$ Menariknya dalam perjalanan pengujian konstitusionalitas terkait penyelenggaraan pemilihan umum serentak terdapat cerita yang patut untuk ditelisik lebih jauh tentang interpretasi hakim konstitusi dalam putusannya.

Putusan Mahkamah Konstitusi No. 14/PUU-XI/2013 perihal pengujian konstitusionalitas atas UU No. 42 Tahun 2008 tentang Pemilihan Umum Presiden dan Wakil Presiden, dalam pengujian ini Mahkamah menghasilkan putusan untuk menerima permohonan pemohon terhadap Pasal 3 ayat (5) UU No. 42 Tahun 2008. Mahkamah menyatakan bahwa kedudukan Pasal 3 ayat (5) tersebut adalah inkonstitusional. Meskipun, pasal tersebut pernah dimohonkan pada putusan sebelumnya sebagaimana diputuskan dalam Putusan Mahkamah Konstitusi No. 51-5259/PUU-VI/2008, namun ketentuan pada Pasal 60 ayat (1) dan ayat (2) UU Mahkamah Konstitusi menyatakan bahwa,

(1) Terhadap materi muatan ayat, pasal, dan/atau bagian dalam undangundang yang telah diuji, tidak dapat dimohonkan pengujian kembali;

\footnotetext{
41 Moh Hatta. (2002). “Kumpulan Pidato II”, Jakarta: PT. Toko Gunung Agung. Hal. 215.

42 Ahmad dan Novendri Nggilu. (2019). "Denyut Nadi Amandemen Kelima UUD 1945 melalui Pelibatan Mahkamah Konstitusi sebagai Prinsip the Guardian of the Constitution" Jurnal Konstitusi, 11 (4): 798.
} 
(2) Ketentuan sebagaimana dimaksud pada ayat (1) dapat dikecualikan jika materi muatan dalam Undang-Undang Dasar Negara Republik Indonesia Tahun 1945 yang dijadikan dasar pengujian berbeda.

Demikian juga pada Pasal 42 ayat (1) dan ayat (2) Peraturan Mahkamah Konstitusi No. 06/PMK/2005 tentang Pedoman Beracara dalam Perkara Pengujian Undang-Undang menyatakan bahwa,

(1) Terhadap materi muatan, ayat, pasal, dan/atau bagian dalam undangundang yang telah diuji, tidak dapat dimohonkan pengujian kembali;

(2) Terlepas dari ketentuan ayat (1) di atas, permohonan pengujian UU terhadap muatan ayat, pasal, dan/atau bagian yang sama dengan perkara yang pernah diputus oleh Mahkamah dapat dimohonkan pengujian kembali dengan syarat-syarat konstitusionalitas yang menjadi alasan permohonan yang bersangkut berbeda.

Menurut Mahkamah, permohonan yang telah diputus pada Putusan Mahkamah Konstitusi No. 51-52-59/PUU-VI/2008, pada pokoknya menggunakan dasar konstitusional Pasal 6A ayat (2) dan Pasal 22E ayat (1), serta ayat (2) UUD 1945, sedangkan permohonan yang telah diputus pada Putusan Mahkamah Konstitusi No. 14/PUU-XI/2013 menggunakan dasar pengujian Pasal 1 ayat (2), Pasal 4 ayat (1), Pasal 6A ayat (1) dan ayat (2), Pasal 22E ayat (1) dan ayat (2), Pasal 27 ayat (1), Pasal 28D ayat (1) dan ayat (3), Pasal 28H ayat (1), dan Pasal 33 ayat (4) UUD 1945 dengan argumentasi berbeda. Dengan demikian menurut Mahkamah, berdasarkan Pasal 60 ayat (1) dan ayat (2) UU Mahkamah Konstitusi dan Pasal 42 ayat (1) dan ayat (2) Peraturan Mahkamah Konstitusi No. 06/PMK/2005 tentang Pedoman Beracara dalam Perkara Pengujian Undang-Undang, Mahkamah dapat menguji lagi atas Pasal 3 ayat (5) UU No. 42 Tahun 2008.

Pada putusan ini, Mahkamah menyatakan bahwa Pasal 3 ayat (5) UU No. 42 Tahun 2008 merupakan pasal yang inkonstitusional. Hal ini dilatarbelakangi dengan penggunaan metode interpretasi original intent oleh Mahkamah dimana Mahkamah berpandangan bahwa dengan diselenggarakannya pemilu serentak maka akan terwujudnya penguatan sistem pemerintahan presidensiil sebagaimana kesepakatan 
Badan Pekerja Majelis Permusyawaratan Rakyat saat melakukan pembahasan Perubahan UUD 1945 adalah memperkuat sistem presidensiil. ${ }^{43}$

Berdasarkan argumentasi Mahkamah bahwa dengan desain pemilu tidak serentak seperti pelaksanaan pemilu selama ini, tidak dapat mewujudkan harapan yang tersirat oleh konstitusi yaitu terwujudnya penguatan sistem pemerintahan presidensiil yang artinya, dengan interpretasi original intent maka dikembalikan makna pemilu menurut konstitusi, sehingga untuk pelaksanaan pemilu selanjutnya dilaksanakan secara serentak dengan harapan memperkuat hubungan legislatif dan eksekutif dalam kerangka check and balances sehingga akan menciptakan pemerintahan yang lebih stabil dan efektif dalam konteks sistem pemerintahan presidensiil yang telah diamanatkan oleh UUD 1945.

Pilihan penggunaan original intent terhadap dua putusan di atas menimbulkan implikasi yang berbeda, Putusan No.005/PUU-IV/2006 yang memunculkan stigma MK sebagai lembaga hegemonik yang mengancam keseimbangan check and balances, sementara Putusan No.14/PUU-XI/2013 dinilai guna memperkuat sistem presidensiil.

Dua putusan yang berbanding terbalik ini seakan memperlihatkan inkonsistensi Mahkamah Konstitusi dalam memutus perkara dan memperlihatkan konteks politik serta hukum (politico-legal) di Indonesia yang mempengaruhi MK dalam membuat suatu putusan. Pusaran politik dan hukum yang mempengaruhi cara pengadilan membuat putusan sendiri secara khusus menjadi dasar seorang ahli hukum tata neara asal Afrika Selatan Theunis Roux untuk membuat klasifikasi tipologi pengadilan konstitusi diantaranya, pengadilan konstitusi Principled, Constrained, Unconstrained, dan Political Court. ${ }^{44}$

Penggunaan metode interpretasi original intent saja tidaklah cukup dijadikan dasar dalam menilai pertentangan norma hukum, hakim harus mengelaborasi kemungkinankemungkinan penggunaan metode interpretasi lain yang tentu menyebabkan implikasi lain. Bercermin dari dua putusan di atas, penggunaan metode interpretasi original intent saja menimbulkan implikasi yang berbeda, artinya penggunaan original

\footnotetext{
43 Putusan Mahkamah Konstitusi No. 14/PUU-XI/2013, Hal. 78.

${ }^{44}$ Lailani Sungkar dan Abdurrachman Satrio. (2018). "Tipologi Mahkamah Konstitusi Indonesia dalam Pusaran Politik dan Hukum: Kajian paada Putusan tentang Pemilu Serentak”. Jurnal Majelis, 7 (7): 26
} 
intent harus tepat dan selektif dan benar-benar memperhatikan nilai-nilai yang terkandung dalam Pancasila dan hakim harus menemukan makna keadilan menurut konstitusi.

\subsection{Interpretasi Mahkamah Konstitusi Terkait Konsep Otonomi Daerah}

Dalam Putusan MK Nomor 32/PUU-X/2012 Mahkamah berpendapat sebagai berikut, "Bahwa sebagai negara kesatuan maka seluruh wilayah Indonesia adalah wilayah Negara Kesatuan Republik Indonesia. Pasal 18 ayat (1) UUD 1945 menyatakan "Negara Kesatuan Republik Indonesia dibagi atas daerah-daerah provinsi dan daerah provinsi itu dibagi atas kabupaten dan kota, yang tiap-tiap provinsi, kabupaten, dan kota itu mempunyai pemerintahan daerah, yang diatur dengan undang-undang". Adapun maksud kata "dibagi" dalam Pasal tersebut adalah untuk menekankan yang ada lebih dahulu adalah wilayah Negara Kesatuan Republik Indonesia. Adapun pembagian itu mengindikasikan wilayah provinsi/kabupaten/kota tidak lain adalah wilayah kesatuan Republik Indonesia yang untuk hal-hal tertentu kewenangannya dilimpahkan kepada provinsi/kabupaten/kota untuk mengaturnya. Bahwa UUD 1945 dengan sengaja mengambil kata "dibagi" karena untuk menghidari kata "terdiri dari" atau "terdiri atas". Tujuannya adalah untuk menghindari konstruksi hukum bahwa wilayah provinsi/kabupaten/kota eksistensinya mendahului dari eksistensi wilayah Negara Kasatuan Republik Indonesia. Dengan demikian wilayah provinsi/kabupaten/kota adalah wilayah administrasi semata dari wilayah Negara Kesatuan Republik Indonesia, yang berbeda dengan negara federal; Pelaksanaan Pasal 18 ayat (1) UUD 1945 menjadi kewenangan sepenuhnya dari pembentuk UndangUndang untuk membagi wilayah termasuk menetapkan batas-batas wilayahnya. Wilayah provinsi/kabupaten/kota bersifat relatif. Artinya tidak menjadi wilayah yang mutlak dari sebuah provinsi/kabupaten/kota yang tidak dapat diubah-ubah batasbatasnya. Hal demikian tercermin dalam UndangUndang Nomor 32 Tahun 2004 tentang Pemerintahan Daerah sebagaimana diubah dengan Undang-Undang Nomor 12 Tahun 2008 tentang Perubahan Kedua Atas Undang-Undang Nomor 32 Tahun 2004 tentang Pemerintahan Daerah (Lembaran Negara Republik Indonesia Tahun 2008 Nomor 59, Tambahan Lembaran Negara Republik Indonesia Nomor 4844, selanjutnya disebut UU Pemda) bahwa wilayah provinsi/kabupaten/kota berdasarkan alasan tertentu bisa berubah dengan adanya penggabungan atau pemekaran sebagaimana 
diatur dalam Pasal 4 ayat (3) UU Pemda yang menyatakan, "Pembentukan daerah dapat berupa penggabungan beberapa daerah atau bagian daerah yang bersandingan atau pemekaran dari satu daerah menjadi dua daerah atau lebih"; 45

Dalam putusan di atas, Mahkamah menggunakan metode penafsiran gramatikal. Mahkamah menafsirkan frasa "dibagi” dalam Pasal 18 ayat (1) UUD 1945. Mahkamah menegaskan maksud kata "dibagi" dalam Pasal tersebut adalah untuk menekankan yang ada lebih dahulu adalah wilayah Negara Kesatuan Republik Indonesia.

Selanjutnya MK juga menggunakan penafsiran historis atau original intent. Mahkamah menafsirkan pemilihan frasa "dibagi" dalam pasal 18 ayat (1) UUD1945 digunakan oleh perancang konstitusi daripada frasa "tediri dari" atau "terdiri atas" dengan tujuan untuk menghindari konstruksi bentuk pembagian wilayah dengan sistem negara federal yang mendahulukan eksistensi wilayah provinsi/kabupaten/kota.

MK juga menggunakan metode penafsiran teleologis. Metode penafsiran ini dapat dilihat ketika Mahkamah dalam pendapatnya dalam paragraf [3.13.1] mengemukakan bahwa "Bahwa UUD 1945 dengan sengaja mengambil kata "dibagi" karena untuk menghidari kata "terdiri dari" atau "terdiri atas". Tujuannya adalah untuk menghindari konstruksi hukum bahwa wilayah provinsi/kabupaten/kota eksistensinya mendahului dari eksistensi wilayah Negara Kasatuan Republik Indonesia. Dengan demikian, wilayah provinsi/kabupaten/kota adalah wilayah administrasi semata dari wilayah Negara Kesatuan Republik Indonesia, yang berbeda dengan negara federal".

Putusan hakim secara umum, termasuk didalamnya putusan hakim Mahkamah Konstitusi, idealnya harus menjadi solusi untuk menyelesaikan suatu masalah "to settle of dispute", bahkan wajib dihindari dengan diputuskan suatu masalah akan menimbulkan masalah hukum yang baru. Oleh karenanya penemuan hukum oleh hakim "rechtsvinding" menjadi keniscayaan bagi hakim, dan setidaknya tiga asas, yang selalu harus menjadi pedoman hakim dalam memutus suatu perkara yaitu asas kepastian hukum, asas keadilan dan asas manfaat. ${ }^{46}$

\footnotetext{
45 Putusan Nomor 32/PUU-X/2012, paragraf [3.13.1], Hal. 190.

46 Mahrus Ali, dkk. (2018). “Tenggang Waktu Konstitusionalitas dan Kebersesuaian Undang-Undang dengan UUD 1945 dalam Putusan Mahkamah Konstitusi”. Jurnal Konstitusi, 15 (4): 850
} 
Mahkamah dalam melakukan penafsiran terkait dengan frasa "dibagi" dalam Pasal 18 ayat (1) UUD 1945 menggunakan banyak metode interpretasi. Di balik pemaknaan frasa "dibagi" tersebut, Mahkamah hendak mendudukkan kembali posisi pemerintah daerah dengan pemerintah pusat dalam kerangka negara kesatuan. Setelah amandemen konstitusi dan rezim otonomi daerah berlaku, kekuasaan daerah menjadi luas sehingga Mahkamah hendak menempatkan kembali otonomi daerah tetap harus berjalan dalam kerangka konsep negara kesatuan. Mahkamah menegaskan kembali konsep negara kesatuan yang dianut oleh Indonesia bukan negara federal. Sesuai dengan amanah dari pendiri bangsa bahwa bentuk negara adalah kesatuan bukan negara federal sehingga dalam hal pembagian wilayah yang menjadi dasar utama adalah kesatuan wilayah Indonesia bukan wewenang pemerintah daerah.

\section{Kesimpulan}

Dari uraian di atas maka dapat dilihat bahwa dalam menginterpretasikan konstitusi, hakim bebas menggunakan metode interpretasi apapun. Dalam menginterpretasikan konsep hak menguasai atas negara, MK mengggunakan metode teleologis. Kemudian dalam menginterpretasikan konsep pemilu serentak, MK menggunakan metode original intent. Sedangkan dalam menginterpretasikan konsep otonomi daerah khususnya terkait dengan frasa 'dibagi', MK menggunakan berbagai metode interpretasi seperti gramatikal, original intent, dan teleologis.

Meskipun hakim bebas dalam menggunakan metode interpretasi, namun kebebasan memilih dan menggunakan metode interpretasi tersebut harus tetap berada dalam koridor Pancasila dan UUD NRI 1945. Hakim harus cermat, mampu memperhatikan, menggali hakekat atau merefleksikan suatu ketentuan pasal di dalam UUD sesuai dengan nilai-nilai Pancasila dan UUD NRI 1945 itu sendiri. Hal ini akan menjadikan putusan MK lebih mencerminkan keadilan bagi semua pihak. Sebagai lembaga penafsir konstitusi untuk mengelaborasi nilai-nilai yang terdapat dalam UUD NRI 1945.

\section{Referensi}

Buku:

Amsari, Feri. (2011). "Perubahan UUD 1945: Perubahan Konstitusi Negara Kesatuan

Republik Indonesia Melalui Keputusan Mahkamah Konstitusi”. Jakarta: RajaGrafindo Persada. 
Choirie, A. Effendi. (2003). “Privatisasi vs Neo Sosialisme Indonesia”. Jakarta: LP3S.

Djokosoetono. (2006). "Kuliah Hukum Tata Negara”. Jakarta: In-Hill-Co.

Hatta, Moh. (2002). “Kumpulan Pidato II”, Jakarta: PT. Toko Gunung Agung.

Manan, Bagir dan Harijanti, Susi Dwi. (2015). Memahami Konstitusi: Makna dan Aktualisasi”. Jakarta: RajaGrafindo.

Mas, Marwan. (2011). “Pengantar Ilmu Hukum”. Cetakan Pertama. Jakarta: Ghalia Indonesia.

Mertokusumo, Soedikno. (2014). “Penemuan Hukum”. Yogyakarta: Cahaya Atma Pustaka.

Rosenfeld, Michel dan Sajo, Andras. (2012). "Types of Constitution" dalam The Oxford Handbook of Comparative Constitutional Law, Oxford: Oxford University Press.

Strauss, David A. (2010). “The Living Constitution”. Oxford: Oxford University Press.

Jurnal:

Ahmad dan Nggilu, Novendri. (2019). “Denyut Nadi Amandemen Kelima UUD 1945 melalui Pelibatan Mahkamah Konstitusi sebagai Prinsip the Guardian of the Constitution" Jurnal Konstitusi, 11 (4) : 786-808

Ali, M. Mahrus, dkk. (2018). “Tenggang Waktu Konstitusionalitas dan Kebersesuaian Undang-Undang dengan UUD 1945 dalam Putusan Mahkamah Konstitusi”. Jurnal Konstitusi, 15 (4) : 837-857

Hardianto, Danang. (2014). "Hakim Konstitusi Adalah Hati dalam Tubuh Mahkamah Konstitusi". Jurnal Konstitusi, 11 (2) : 316-332

Isra, Saldi dan Amsari, Feri. (2008). "Perubahan Konstitusi melalui Tafsir MK", Jurnal Konstitusi Pusako FHUA, 1 (1)

Manan, Bagir. (2010) “Beberapa Persoalan Paradigma Setelah atau Akibat Perubahan UUD 1945". Jurnal Konstitusi, 2 (2) : 9-10

Safaat, Muchamad Ali, dkk. (2017). "Pola Penafsiran Konstitui dalam Putusan Mahkamah Konstitusi Periode 2003-2008 dan 2009-2013". Jurnal Konstitusi, 14 (2): 235-261

Sakirman. (2017). Tafsir Hukum Atas Posisi Ganda Hakim di Indonesia. Jurnal Konstitusi, 14 (1) : 189-212

Sanden, Joachim. (2003). "Methods of Interpreting The Constitution; Estonia's Way in an Increasingly Integrated Europe", Juridica International, $8: 130$ 
Soeprapto. (2005). "Implementasi Pancasila Dalam Kehidupan Bermasyarakat, Berbangsa dan Bernegara”, Jurnal Ketahanan Nasional, 10 (2) : 19

Sungkar, Lailani dan Satrio, Abdurrachman. (2018). “Tipologi Mahkamah Konstitusi Indonesia dalam Pusaran Politik dan Hukum: Kajian paada Putusan tentang Pemilu Serentak". Jurnal Majelis, 7 (7) : 26

Winayanti, Nia Kania. (2018). "Rekonstruksi Makna Hak Menguasai Negara Berdasarkan Pasal 33 Ayat (3) UUD 1945 dalam Mewujudkan Ketahanan Ekonomi Nasional". Jurnal Majelis, 7 (7) : 89-100

\section{Internet:}

Alan Watson, "Legal Transplant”, Dilansir dari

https://en.wikipedia.org/wiki/Legal transplant, pada 20 Juni 2019.

Saldi Isra dan Feri Amsari, "Perubahan Konstitusi Melalui Tafsir Mahkamah Konstitusi", Dilansir dari

http://feriamsari.wordpress.com/2009/01/29/perubahan-konstitusi-melalui-tafsir$\underline{m k}$, diakses pada 20 Juni 2019.

\section{Lain-lain:}

Susi Dwi Harijanti, Perkuliahan Hukum Konstitusi, Bandung, Magister Ilmu Hukum Unpad, 2018.

Undang-Undang Dasar 1945 Perubahan

Putusan Mahkamah Konstitusi No. 005/PUU-IV/2006

Putusan Mahkamah Konstitusi No. 001-021-022/PUU-I/2003

Putusan Mahkamah Konstitusi No. 002/PUU-I/2003

Putusan Mahkamah Konstitusi No. 008/PUUIII/2005

Putusan Mahkamah Konstitusi No. 058-059-060-063/PUU-II/2004

Putusan Mahkamah Konstitusi No. 14/PUU-XI/2013

Putusan Mahkamah Konstitusi No. 21-22/PUU-V/2007

Putusan Mahkamah Konstitusi No. 28/PUU-XI/2013

Putusan Mahkamah Konstitusi No. 3/PUU-VIII/2010

Putusan Mahkamah Konstitusi No. 49/PUU-IX/2011

Putusan Mahkamah Konstitusi Nomor 32/PUU-X/2012 